
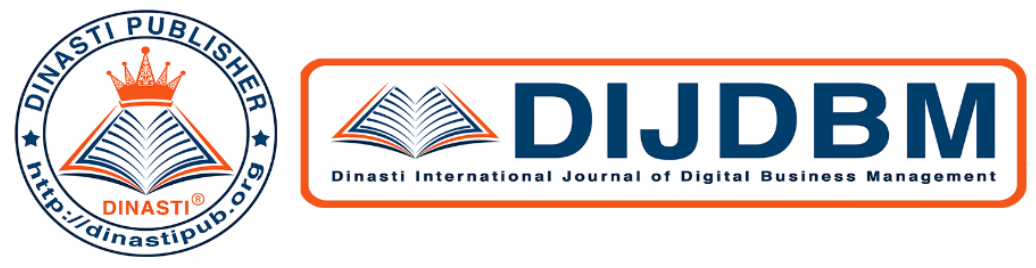

+6281387654578 (9)

+6281387654578 @

https://dinastipub.org/DIJDBM (2)

dinasti-info@gmail.com G.

\title{
DETERMINANT FACTOR OF LISTENER LOYALTY TO POP FM JAKARTA
}

Agung Sehpudin ${ }^{1}$, Achmad Fachrodji ${ }^{2}$

1) Mercu Buana University, Jakarta, Indonesia

${ }^{2)}$ Mercu Buana University, Jakarta, Indonesia

ARTICLE INFORMATION

Received: 31 August 2020

Revised: 26 September 2020

Issued: 9 Novemver 2020

Corresponding author: Agung Sehpudin

E-mail:

agungsehpudin@gmail.com achmadfachrodji@gmail.com

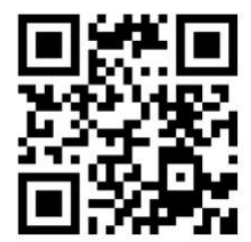

DOI:10.31933/DIJDBM
Abstract: This study aims to analyze the influence of radio programs, broadcasters and transmitter power on listening to Pop FM radio Jakarta and listeners loyalty. Primary data were obtained from questionnaires and secondary data were obtained from field research such as interviews with companies. The population of this study were all listeners of Pop FM Jakarta radio in Jabodetabek in May-June with a total sample of 210 people. The analytical method used is the LISREL version 8.80 Structural Equation Modeling (SEM). The results showed that radio programs, broadcasters and transmitter power had a significant positive effect on interest in listening to radio. Meanwhile, radio programs, broadcasters and transmitter power also have a significant positive effect on radio listeners' loyalty. The R Square value is 0.75 that in this study the broadcast program variables, announcers and transmitter power contributed $75 \%$, the rest was influenced by other variables by $25 \%$.

Keywords: Radio program, announcer, transmitter power, listener loyalty.

\section{INTRODUCTION}

Radio is a source of entertainment and information spread through air. Radio is a medium which simple and practical in use. Due to its practical, radio has its own space in the hearts of its enthusiasts. Even though radio is not as popular as it used to, but its basic idea of wireless communication remains important. Radio is not only maintained, but also Re-new in quality by digital radio technology. As quoted from several sources, digital radio is different from online radio. In online radio, listeners could listen to broadcasts using internet-based devices. So it can only be heard as long as it is connected to the internet. While digital radio does not require the internet, it is the same as FM / AM radio which requires a special radio box. 
Overall, the media consumption in cities both in Java and outside Java shows that television is still the main medium consumed by Indonesians $(95 \%)$, followed by internet $(33 \%)$, radio $(20 \%)$, newspapers $(12 \%)$, Tabloids $(6 \%)$ and Magazines $(5 \%)$. However, when we look further, it turns out that there are very interesting different between the patterns of media consumption in cities in Java compared to cities outside Java. Television media consumption is higher outside Java (97\%), followed by Radio (37\%), Internet (32\%), Newspapers (26\%), Cinemas (11\%), Tabloids (9\%) and Magazines (5\%). Meanwhile, in Java, internet consumption is only slightly higher at $34 \%$. From these data, it could be viewed that there are still quite a few radio listeners today, including in Jakarta. From many radios in Jakarta, the highest rating is i-Radio.

Table 1. Radio Ratings in Jakarta

\begin{tabular}{|c|c|c|c|}
\hline Radio Station & Radio Logo & Rating & Information \\
\hline i-Radio FM & jiradic & 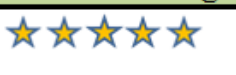 & Pop, Top 40 \\
\hline Hard Rock FM Jakarta & HardRock & 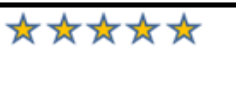 & Rock, Top 40 \\
\hline Prambors FM & Pasivars & 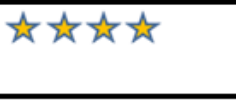 & Pop, Top 40 \\
\hline Delta FM & Delta ${ }^{\mathrm{FM}}$ & 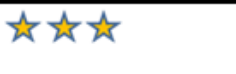 & Pop \\
\hline Kiss FM & KISS & 支衣市 & Pop, Top 40 \\
\hline 98,7 Gen FM & 崰得 & 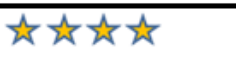 & Pop, Top 40 \\
\hline Mustang $88 \mathrm{FM}$ & & 衣衣市 & Pop, Тop 40 \\
\hline
\end{tabular}

With these large number of radio stations in Jakarta, competition to listeners has continues growth. Because the more listeners has listen to the radio, the greater opportunity to get advertisements which are a source of income from radio. So many radios have innovated both in terms of programs and the format of the songs played, one of that is Pop FM radio Jakarta.

Based on these interview results which conducted by the author to Pop FM radio Jakarta, it shows that the number of listeners of Pop FM Jakarta radio is not always directly proportional to the advertising revenue they earned each year. According to Abby Zaky as the Program Director, this is due to the development of social media and new internet-based media which greatly affects the number of radio listeners. Beside that, there has lots advertisers today, many of them consider relate to the effectiveness of radio advertising on sale of their products, Therefore so many of them use radio as offline promotions such as events and others to sponsor their products. 
Table 2. Comparison of Number of Listeners and FM Pop Ad Income

\begin{tabular}{|c|c|c|c|}
\hline Year & $\begin{array}{c}\text { Number of Listen ers } \\
\text { (people) }\end{array}$ & $\begin{array}{c}\text { Advertising revenue/year } \\
\text { (million rupiah) }\end{array}$ & $\begin{array}{c}\text { Information } \\
\text { (Pop Indo : Western) }\end{array}$ \\
\hline 2014 & 1,3 million & 300 & $80: 20$ \\
2015 & 1,2 million & 350 & $80: 20$ \\
2016 & 1,1 million & 400 & $80: 20$ \\
2017 & 0,9 million & 350 & $60: 40$ \\
2018 & 0,8 million & 150 & $60: 40$ \\
2019 & 1,2 million & 200 & $60: 40$ \\
\hline
\end{tabular}

Then Aby Zacky were also explained that Pop FM Jakarta has three programs that can be said to be superior programs, namely KpopZone which broadcast every Saturday and Sunday at 19.00-22.00 WIB and manages get around 250 listeners every time it airs, a weekday program with the name JAGO ( Jawara Goyang Jakarta) which broadcast every Monday-Friday at 11.00-15.00 WIB and manages get around 200 listeners every time it airs, and the Night Action program which broadcast at 21.00-23.00 WIB every Monday-Friday, gained of 70 listeners per air.

The more listeners of a radio, the stronger the radio can maintain its existence. It is also possible to attract advertisers to promote their products. Based on these pre-research that conducted by the author on 15 radio listeners who listened to Pop FM radio in Jabodetabek, several factors made them listen to radio, such as songs, advertisements and prizes that were part of a radio program, then attention, sound and appearance were part of the broadcaster. And the last is the signal which the strength of the radio transmitter, so the authors take and classify it into three variables.

Based on definition above, the author was interested to conducted research on Pop FM radio Jakarta. The author wants to know whether the marketing strategy which adopted by Pop FM radio is correct in increasing or getting the number of listeners. Therefore, the writer intends to do research with the title "Determinant factor of Listener Loyalty to Pop FM Jakarta".

\section{LITERATURE REVIEW}

\section{Radio Program}

Pringle-Starr-McCavitt (1991) in Morissan (2018) explained that the programs from most radio stations are dominated by a main content or sound element known as format. All radio station formats can be grouped into three major groups, which is: 1) Music format; 2) Information Format; and 3) Specialty format.

\section{Radio Announcer}

Broadcasters as the spearhead of broadcasting, of course, identical as representatives of their radio stations. Meaning that the broadcaster is a reflects of station identity. An announcer needs to realize that they are representation of broadcast content and the image of their company. To become a great announcer, liked by so many listeners and capable to 
become a spokesperson for a radio station, Announcer Should have these three Basics of mastery, such as: 1) Skill; 2) Knowledge; and 3) Attitude. (Triartanto, 2010).

\section{Transmitter Power}

The frequency channel which owned by a broadcasting station determines the type of signal spread what is called "propagation" which plays a role of determining the area of the signal propagation coverage area. However, there had several other factors which also influenced the wide coverage of broadcast frequencies such as, season, weather factors, broadcast time and interference. (Morissan, 2018).

\section{Listening Interest}

Purchase interest is something related to consumer's plan to buy a certain product at a certain time. Real purchases occur when consumers already have an interest to buy a product. According to Margaretha (2018)said that to attract listeners' interest, there are need several strategies that should be done, which is placing this broadcast programs according to the target audience. Yeh (2015: 38) in Arifki (2018) describes the dimensions of interest divide into four parts, namely: 1) Valuable purchase; 2) The most preference; 3) Willingness to trial; and 4) Recommendation.

\section{Loyalty}

Loyalty is a commitment from customers which forms as customer loyalty to a product or service, so the customer will make continuous purchases of that selected product or services. According to Tjiptono (2012) consumer loyalty is a consumer's commitment to a brand, based on very positive attitude and reflected in consistent repeat of purchases. The dimensions to measuring customer loyalty are 1) Repeat Purchase; 2) Purchasing between product lines or services; 3) Referalls; and 4) Retention. (Tjiptono, 2012).

\section{Previous Research}

Vinda Maya's (2017) research found that the mismatch between the program and the listeners' tastes has resulted in decrease of the listener numbers as illustrated by the results from radio rating from year to year. According to Anindita (2017)which stated that the quality of broadcasters had positive and significant influence towards listener satisfaction and its loyalty, this in line with Dianne Raab's research (2013)defined that radio broadcasts are not just saying what's in the head, re-reading broadcast scripts will also help to become a good broadcasters. In her research, Liliyana (2014) stated that transmitter power had impact to radio listeners' loyalty. This means that the weak of power transmitter will had impact to audio that produced in the broadcast. Poor audio in resulted will impact those loyalty and interest of radio listeners. 


\section{Theoretical Framework and Hypothesis}

Based on the aims of research, literature review which mentioned above then Theoretical framework for this research could be drawn as its follows:

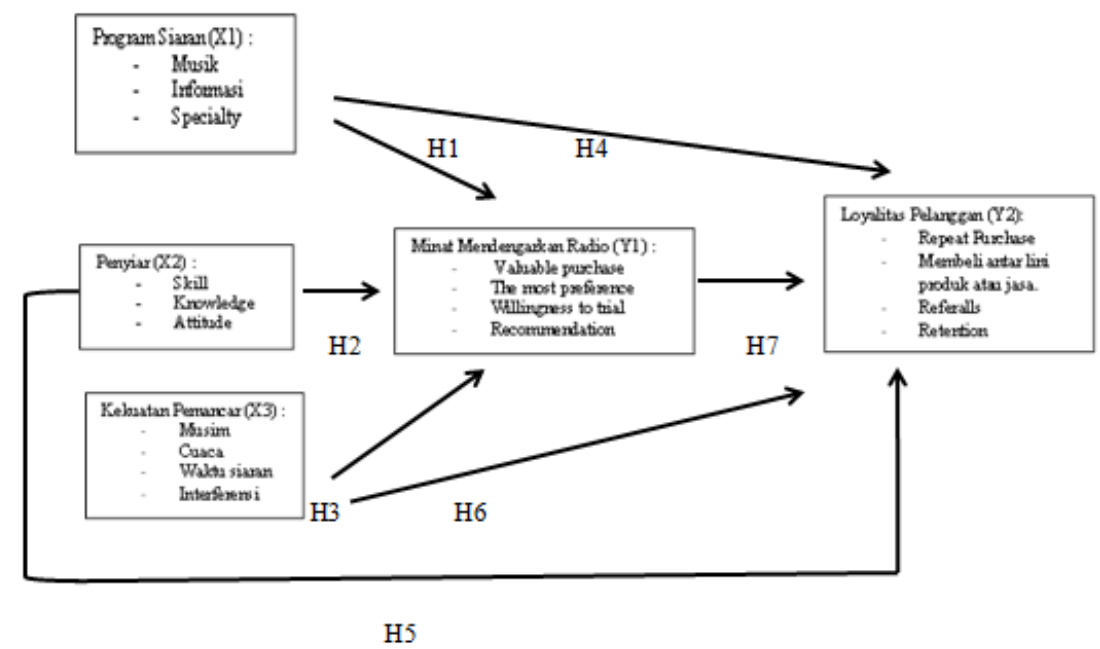

Figure 1. Theoretical Framework

Based on these literature review, several hypothesis from this research could be served as follows: 1) Broadcast/radio programs had significant and positive impact towards listening interest towards radio; 2) Announcer had significant and positive impact on listening interest to radio; 3) Transmitter power had significant and positive influence towards listening interest towards radio; 4) Radio programs had significant and positive influence towards listener loyalty; 5) Radio Announcers had significant and positive impact towards listener loyalty; 6) Transmitter power had significant and positive impact over listener loyalty; and 7) Listening Interest in listen to radio had significant and positive impact towards listener loyalty.

\section{RESEARCH METHODS}

In this research, the researchers used causal analysis method with purpose to determine how much influence from Broadcasting programs, Announcer and transmitter power had impact over interest to listening radio. The independent variables in this research consist of broadcast programs, Announcers and transmitter power. The intervening latent variable was listening interest. The dependent variable in this research was radio listener loyalty. In this research, the Population means the number of POP FM listeners for one month, taken from the average number of listeners per year divided by 12 . So, the population is 80,000 listeners throughout Jabodetabek with criteria aged 14 years and up. This research designed has 42 indicators, so the number of samples in this research was $42 \times 5=210$ respondents. Data collection method used non-probability sampling with purposive sampling method to choosing the respondents. While data analysis technique in this study used Structural Equation Modeling (SEM) with assist of the LISREL (Linear Structural Relations) version 8.80 program. 


\section{FINDINGS AND DISCUSSION}

\section{Demographic Characteristics of Respondents}

Based on these characteristics of 210 respondents who are listeners from Pop FM Radio, it was found that the majority of Pop FM Radio listeners were women (62.38\%) aged between 31-40 years (48.10\%) and have minimum high school education (49.52\%) meaning that the majority of listeners which listen to Pop FM radio were women who have good education to received information, and have a lot of activities indoors or outdoors and still in their productive age who need entertainment through radio broadcasts.

\section{Validity and Reliability Test of SEM}

Based on these test results, there are 8 indicators as observed variables in these latent variable of broadcast programs that passed the validity test, because all these 8 variable indicators had loading factors value $>0.50$. While these reliability test results from broadcast program variables had produced a good reliability value with Construct Reliability (CR) value $=0.98>0.7$, and Variance Extracted $(\mathrm{VE})$ value was $0.83>0.50$. Thus the broadcast program latent variable $(\mathrm{X} 1)$ met the validity and reliability test requirements.

Table 3. The Results of Validity and Reliability Test from Broadcast Program Variables

\begin{tabular}{|c|c|c|c|c|c|c|}
\hline \multirow{2}{*}{ Indicator Code } & \multirow{2}{*}{ SLF } & \multirow{2}{*}{ Standard Errors } & \multirow{2}{*}{$\mathrm{e}^{2}$} & \multicolumn{2}{|c|}{ Reliability } & \multirow{2}{*}{ Information } \\
\hline & & & & $\mathrm{CR}=0,70$ & $\mathrm{VE}=0,5$ & \\
\hline PS1 & 0.88 & 0.18 & 0.03 & \multirow{8}{*}{0.98} & \multirow{8}{*}{0.83} & Valid \\
\hline PS2 & 0.89 & 0.15 & 0.02 & & & Valid \\
\hline PS3 & 0.94 & 0.09 & 0.01 & & & Valid \\
\hline PS4 & 0.93 & 0.10 & 0.01 & & & Valid \\
\hline PS5 & 0.92 & 0.12 & 0.01 & & & Valid \\
\hline PS6 & 0.88 & 0.16 & 0.03 & & & Valid \\
\hline PS7 & 0.88 & 0.18 & 0.03 & & & Valid \\
\hline PS8 & 0.82 & 0.29 & 0.08 & & & Valid \\
\hline
\end{tabular}

Based on these test results, there are 12 indicators that observed in this latent variable of announcers which passed the validity test, because all these 12 variable indicators had loading factors value $>0.50$. Meanwhile, the reliability test results from announcer had produced a good reliability value where the Construct Reliability $(\mathrm{CR})$ value $=0.99>0.7$ with Variance Extracted (VE) value was $0.85>0.50$. Thus these latent variable of Announcers (X2) met the requirements of validity and reliability test. 
Table 4. The Results of Validity and Reliability from Announcers Variables

\begin{tabular}{lcccccc}
\hline \multirow{2}{*}{ Indicator Code } & \multirow{2}{*}{ SLF } & Standard Errors & \multirow{2}{*}{$\mathbf{e}^{\mathbf{2}}$} & \multicolumn{2}{c}{ Reliability } & \multirow{2}{*}{ Information } \\
\cline { 1 - 3 } & & & & $\mathbf{C R}=\mathbf{0 , 7 0}$ & $\mathbf{V E}=\mathbf{0 , 5}$ & \\
\hline P1 & 0.93 & 0.11 & 0.01 & & & Valid \\
\hline P2 & 0.93 & 0.11 & 0.01 & & Valid \\
\hline P3 & 0.94 & 0.09 & 0.01 & & Valid \\
\hline P4 & 0.91 & 0.13 & 0.02 & & Valid \\
\hline P5 & 0.95 & 0.08 & 0.01 & & & Valid \\
\hline P6 & 0.93 & 0.12 & 0.01 & 0.99 & $\mathbf{0 . 8 5}$ & Valid \\
\hline P7 & 0.87 & 0.17 & 0.03 & & & Valid \\
\hline P8 & 0.88 & 0.19 & 0.04 & & Valid \\
\hline P9 & 0.88 & 0.22 & 0.05 & & Valid \\
\hline P10 & 0.90 & 0.18 & 0.03 & & Valid \\
\hline P11 & 0.89 & 0.18 & 0.03 & & Valid \\
\hline P12 & 0.86 & 0.21 & 0.04 & & Valid \\
\hline
\end{tabular}

Based on these test results, there are 5 indicators which observed in this latent variable of transmitter power that passed validity test, because all these 5 variable indicators have loading factor values $>0.50$. While the reliability test results from this transmitter power variable earned a good reliability value with Construct Reliability $(\mathrm{CR})$ value $=0.97>0.7$ and Variance Extracted (VE) value was $0.86>0.50$. Thus these latent transmitter power variable met these requirements from validity and reliability test.

Table 5. Test Results of Validity and Reliability test from Transmitter Power Variable.

\begin{tabular}{|c|c|c|c|c|c|c|}
\hline \multirow{2}{*}{ Indicator Code } & \multirow{2}{*}{ SLF } & \multirow{2}{*}{ Standard Errors } & \multirow{2}{*}{$\mathrm{e}^{2}$} & \multicolumn{2}{|c|}{ Reliability } & \multirow{2}{*}{ Information } \\
\hline & & & & $C R=0,70$ & $\mathrm{VE}=0,5$ & \\
\hline KP1 & 0.96 & 0.06 & 0.00 & \multirow{5}{*}{0.97} & \multirow{5}{*}{0.86} & Valid \\
\hline KP2 & 0.86 & 0.16 & 0.03 & & & Valid \\
\hline KP3 & 0.91 & 0.13 & 0.02 & & & Valid \\
\hline KP4 & 0.92 & 0.12 & 0.01 & & & Valid \\
\hline KP5 & 0.86 & 0.19 & 0.04 & & & Valid \\
\hline
\end{tabular}

Based on test results, there are 8 indicators from observed variables in this latent variable of "listening to the radio" which passed validity test, because all these 8 variable indicators had loading factors value $>0.50$. While reliability test results from this variable" listening to the radio" produced a good reliability value with Construct Reliability value (CR) $=0.98>0.7$ and Variance Extracted $(\mathrm{VE})$ value was $0.84>0.50$. Thus these latent variable "listening to the radio" met those criteria of validity and reliability test.

Table 6. The Results from Validity and Reliability Test for "Listening to Radio" Variables

\begin{tabular}{|c|c|c|c|c|c|c|}
\hline \multirow{2}{*}{ Indicator Code } & \multirow{2}{*}{ SLF } & \multirow{2}{*}{ Stand ard Errors } & \multirow{2}{*}{$\mathrm{e}^{2}$} & \multicolumn{2}{|c|}{ Reliability } & \multirow{2}{*}{ Informatior } \\
\hline & & & & $\mathbf{C R}=0,70$ & $\mathrm{VE}=0,5$ & \\
\hline M1 & 0.87 & 0.20 & 0.04 & \multirow{8}{*}{0.98} & \multirow{8}{*}{0.84} & Valid \\
\hline M2 & 0.88 & 0.18 & 0.03 & & & Valid \\
\hline M3 & 0.92 & 0.13 & 0.02 & & & Valid \\
\hline M4 & 0.93 & 0.10 & 0.01 & & & Valid \\
\hline M5 & 0.92 & 0.12 & 0.01 & & & Valid \\
\hline M6 & 0.88 & 0.17 & 0.03 & & & Valid \\
\hline M7 & 0.93 & 0.13 & 0.02 & & & Valid \\
\hline M8 & 0.86 & 0.18 & 0.03 & & & Valid \\
\hline
\end{tabular}


According to these test results, there are 9 variable indicators which observed in these latent variable of customer loyalty that passed the validity test, because all these 9 variable indicators had loading factors value > 0.50. Meanwhile, the reliability test results from customer loyalty variable had produced a good reliability value where the Construct Reliability $(\mathrm{CR})$ value $=0.99>0.7$ with Variance Extracted $(\mathrm{VE})$ value was $0.90>0.50$. Thus these latent Customer Loyalty met the requirements of validity and reliability test.

Table 7. Test Results of Validity and Reliability from Customer Loyalty Variables

\begin{tabular}{|c|c|c|c|c|c|c|}
\hline \multirow{2}{*}{ Indicator Code } & \multirow{2}{*}{ SLF } & \multirow{2}{*}{ Standard Errors } & \multirow{2}{*}{$\mathrm{e}^{2}$} & \multicolumn{2}{|c|}{ Reliability } & \multirow{2}{*}{ Information } \\
\hline & & & & $\mathbf{C R}=\mathbf{0 , 7 0}$ & $\mathrm{VE}=\mathbf{0 , 5}$ & \\
\hline LP1 & 0.89 & 0.13 & 0.02 & \multirow{9}{*}{0.99} & \multirow{9}{*}{0.90} & Valid \\
\hline LP2 & 0.88 & 0.18 & 0.03 & & & Valid \\
\hline LP3 & 0.91 & 0.14 & 0.02 & & & Valid \\
\hline LP4 & 1.00 & 0.01 & 0.00 & & & Valid \\
\hline LP5 & 1.00 & 0.00 & 0.00 & & & Valid \\
\hline LP6 & 0.90 & 0.12 & 0.01 & & & Valid \\
\hline LP7 & 0.91 & 0.15 & 0.02 & & & Valid \\
\hline LP8 & 0.90 & 0.12 & 0.01 & & & Valid \\
\hline LP9 & 1.00 & 0.00 & 0.00 & & & Valid \\
\hline
\end{tabular}

\section{Analysis and Fit Test of Structural Models}

After obtaining these structural model specifications, the next step was to analyzed these statistical Goodness of Fit (GoF) of the entire model. SEM analysis results shows that the structural equation model meets the absolute fit measure requirements (GFI 0.77 was closed to 0.90 (marginal fit), the RMSEA value was $0.063<0.08$ (model fit)); incremental fit measure (NNFI / TLI value $0.99 \geq 0.90$ (fit model), CFI value $0.99 \geq 0.90$ (fit model), RFI value $0.98 \geq 0.90$ (model fit), NFI value $0.98 \geq 0.90$ (fit model), and IFI $0.99 \geq 0.90$ (fit model)); and the parsimonious fit measure (normed chi-square value of $1.839<2.0$ (fit model).

\begin{tabular}{|c|c|c|c|c|}
\hline \multirow{2}{*}{ Goodnes of Fit Size } & \multicolumn{2}{|c|}{ Match Size } & \multirow{2}{*}{\multicolumn{2}{|c|}{$\begin{array}{c}\text { Measurement } \\
\text { Result }\end{array}$}} \\
\hline & Good Fit & Marginal Fit & & \\
\hline Normed Chi-Square $\left(\chi^{2} / \mathrm{df}\right)$ & $<2.0$ & & 1.839 & Fit \\
\hline Root Mean Square Error (RMSEA) & $<0.08$ & & 0.063 & Fit \\
\hline Root Mean Square Residual (RMR) & $<0.05$ & & 0.023 & Fit \\
\hline Goodness of Fit Index (GFI) & $=0.90$ & $0.70<0.90$ & 0.77 & Marginal Fit \\
\hline Normal Fit Index (NFI) & $=0.90$ & $0.80-<0.90$ & 0.98 & Fit \\
\hline Non-Normed Fit Index (NNFI) & $=0.90$ & $0.80-<0.90$ & 0.99 & Fit \\
\hline Comparative Fit Index (CFI) & $=0.90$ & $0.80-<0.90$ & 0.99 & Fit \\
\hline Increamental Fit Index (IFI) & $=0.90$ & $0.80-<0.90$ & 0.99 & Fit \\
\hline Relative Fit Index (RFI) & $=0.90$ & $0.80-<0.90$ & 0.98 & Fit \\
\hline
\end{tabular}

Based on these calculations made, the coefficient of determination that obtained which could be seen that the dependent variable" listening interest to the radio of 0.75 , meaning that 
$75 \%$ from existing variations which explained by these independent variables of broadcast programs, announcers and transmitter power. Meanwhile, the dependent variable listeners loyalty was 0.94 which means that $94 \%$ from existing variations which could be explained by these independent variables from broadcast programs, announcers and transmitter power also listening to radio.

Structural Equations

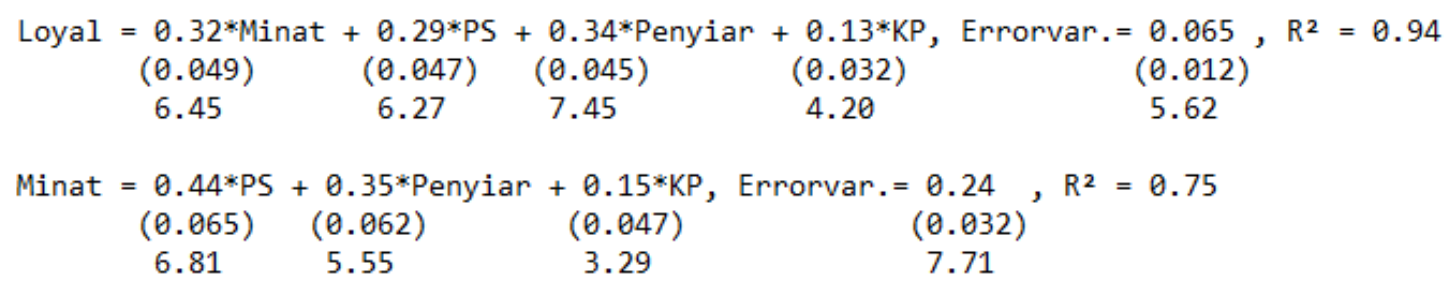

Figure 2. Structural Equation Model Output

\section{Hypothesis Test}

Based on results from these structural model fit test which conducted previously, the seven research hypothesis had proven that there had significant relationship at 95\% confidence level with $t$ value $>1.96$. In general, these conclusion from these hypothesis test results and estimated regression coefficient that could be seen in these interpretation below.

1) The value from $t$-Values $=6.81>1.96$, the coefficient value was positive, which is 0.44 , meaning that these broadcast program variable had positive impact on listening interest to the radio by $44 \%$. Thus these $\mathrm{H} 1$ hypothesis in this research was accepted.

2) The $t-V a l u e s=5.55$ which greater than $t=1.96$, the coefficient value was positive which is 0.35 , meaning that the announcer variable had positive impact towards listening interest to the radio by $35 \%$. Thus $\mathrm{H} 2$ hypothesis in this research was accepted.

3) The t-Values $=3.29>1.96$, the coefficient value was positive, which is 0.15 , meaning that the transmitter power variable had positive impact towards listening interest to the radio by $15 \%$. Thus these $\mathrm{H} 3$ hypothesis in this research was accepted.

4) The $t$-Values $=6.27$ which greater than $t=1.96$, the coefficient value was positive, which equal to 0.29 , meaning that broadcast program variable had positive impact on customer loyalty variable by $29 \%$. Thus these $\mathrm{H} 4$ hypothesis in this research was accepted.

5) The $\mathrm{t}$-Values $=7.45$ which greater than $t=1.96$, so these coefficient value was positive, which is 0.34 , meaning that announcer variable had positive impact on customer loyalty variable by $103.0 \%$. Thus these H5 hypothesis in this research was accepted.

6) The $t$-Values $=4.2$ which greater than $t=1.96$, these coefficient value was positive, which is 0.13 , meaning that transmitter power variable had positive impact towards customer loyalty variable by $13.0 \%$. Thus these H6 hypothesis from this research was accepted.

7) The $t$-Values $=6.45$ which greater than $t=1.96$, these coefficient value was positive, which is 0.32 , meaning that listening interest to the radio had positive impact on customer loyalty variable by $32 \%$. Thus these $\mathrm{H} 7$ hypothesis from this research was accepted. 
Table 9. Hypothesis Test Results

\begin{tabular}{lccc}
\hline \multicolumn{1}{c}{ Relations between con struct } & Estimates & T-Values & Information \\
\hline Broadcast Program > Listening interest to radio & 0.44 & 6.81 & Positive and Significant \\
\hline Announcers > Listening interest to radio & 0.35 & 5.55 & Positive and Significant \\
\hline Transmitter Power > Listening interest to radio & 0.15 & 3.29 & Positive and Significant \\
\hline Broadcast Program > Listener Loyalty & 0.29 & 6.27 & Positive and Significant \\
\hline Announcers > Listener Loyalty & 0.34 & 7.45 & Positive and Significant \\
\hline Transmitter Power > Listener Loyalty & 0.13 & 4.20 & Positive and Significant \\
\hline Listening interest to radio > Listener Loyalty & 0.32 & 6.45 & Positive and Significant \\
\hline
\end{tabular}
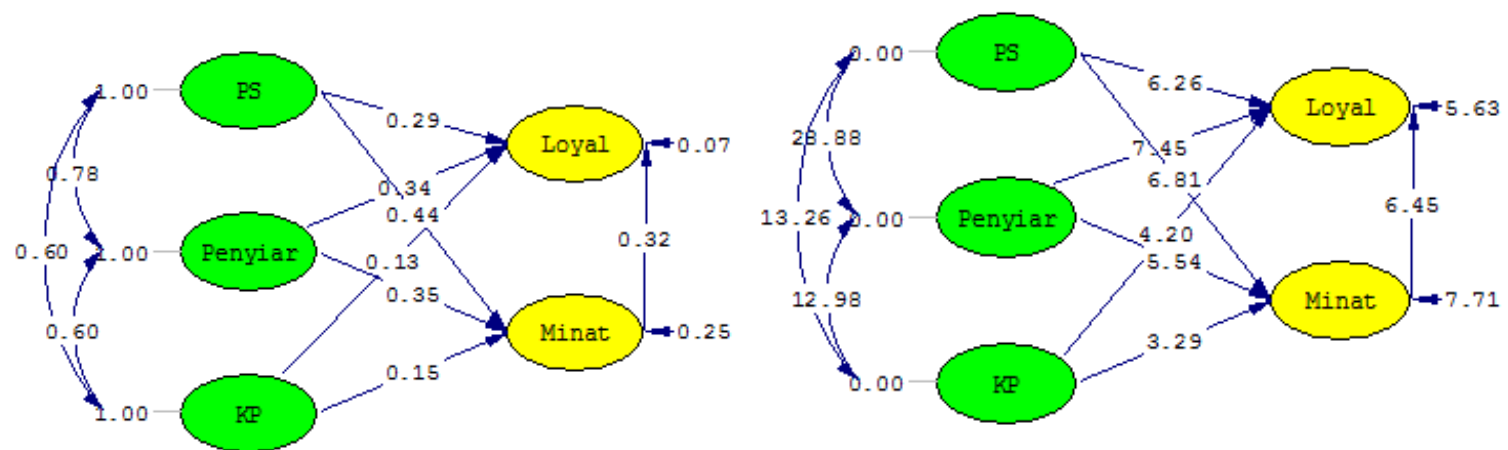

Figure 3. Estimates Structural Model and t-Value Structural Model

\section{Indirect Effect Analysis}

According to test results, the results from indirect influence analysis are as follows:

1) The t-Values $=4.89>1.96$, these coefficient value was positive, which is $0.14(0.44 \times$ 0.32 ), meaning that broadcast program variable had positive impact on customer loyalty variable through listening interest to the radio by $14 \%$.

2) The $t$-Values $=4.32$ which greater than $t=1.96$, these coefficient value was positive, which is $0.11(0.35 \times 0.32)$, meaning that announcer variable had positive impact towards Customer Loyalty variable through the Listening Interest to radio variable by $11.0 \%$.

3) The $t$-Values $=2.94>1.96$, these coefficient value was positive, which equal to $0.05(0.15$ $\times 0.32$ ), meaning that transmitter power variable had positive impact on customer loyalty variable through listening interest to the radio by $5 \%$.

\section{Indirect Effects of KSI on ETA}

$\begin{array}{rrrr} & \text { PS } & \text { Penyiar } & \text { KP } \\ \text { Loyal } & 0.14 & 0.11 & 0.05 \\ & (0.03) & (0.03) & (0.02) \\ & 4.89 & 4.31 & 2.94\end{array}$

Minat

Figure 4. Indirect Influence Result 


\section{CONCLUSION AND SUGGESTION \\ Conclusion}

Based on these research results and discussion in prior chapters, these several conclusions that could be made as follows:

1) Broadcast program variables had positive and significant impact towards listening interest to radio. Meaning that the better the broadcast program, the listening interest to radio will also increase. Broadcast program variable is the variable which have highest influence on listening interest to radio.

2) Announcer variable had positive and significant impact on listening interest to radio. Meaning that the better the broadcasters, the listening interest to the radio will also increase.

3) Transmitter power had positive and significant influence towards listening interest to radio. Meaning that the better transmitter power, Listening interest to the radio will also increase.

4) Broadcast program variables had positive and significant influence on customer loyalty. Meaning that the better broadcast program, the customer loyalty will also increase.

5) Announcer variable had positive and significant impact on customer loyalty. Meaning that the better the broadcasters, the customer loyalty will also increase. Broadcast variable is the variable which has the highest influence on customer loyalty.

6) Transmitter power had positive and significant impact on customer loyalty. Meaning that the better transmitter power, customer loyalty will also increase.

7) Listening interest to radio had positive and significant impact on customer loyalty. Meaning that the better listening interest to the radio, the customer loyalty will also increase.

\section{Suggestion}

Based on these results from this discussion analysis and some of conclusions above, these suggestions that can be given to complement the results such as:

\section{For Agencies}

1) Outcome result from broadcast program which includes music, information and specialty is the main variable to increase listening interest to radio. As well as being more sensitive to current music hyped in order to playing songs or music that currently popular.

2) Announcer factors, especially skills, which are sensitive to economic, political and sociocultural situations need to be maintained to retain those interest in listening to good radio, by providing regular training or training to announcer to digging up their knowledge and their broadcast skills.

3) The low influence from transmitter power on listening interest to radio has something that the company needs to consider, especially during bad weather conditions, by further improving these transmitter quality so the radio would heard clearly whatever conditions. 


\section{For Further Researchers}

The expectation from authors to next further research is they could dig up deeper regarding those variables which impact to affect listening interest to radio. The high influence from broadcast programs on listening interest to radio found that this research opens the possibility to other influences from other variables, such as word of mouth. And because of these high R Square value, its hoped that other researchers could re-test on different research objects.

\section{REFERENCE}

Anindita, T. (2017). Stategi Konvergensi Radio Sebagai Upaya Perluasan Pasar Audience dan Iklan (Studi Kasus pada Swaragama FM, Geronimo FM dan Prambors Radio). Jurnal Komunikasi, 12(1).

Arifki. (2018). Pengaruh Harga, Persepsi Kualitas, Dan Citra Merek Terhadap Keputusan Pembelian Melalui Minat Beli Konsumen Pada Produk Honda Spacy. Tesis. Universitas Mercubuana. Jakarta.

Diane, RS. (2013). Radio Broadcasting and School for The Blind: Existing Program and Fledgling Student-Run Station at The Arizona State Schools For The Deaf and The Blind. Journal of Visual Impairment \& Blindness, 107(2), 152.

Liliyana. (2017). Strategi Program Siaran Radio Dangdut di Jakarta (Studi Kasus Pada Kenaikan Rating Radio Mersi FM Tahun 2014). Jurnal Komunikasi, 8(2).

Margaretha, DSS. (2018). Strategi Manajemen Program Siaran Radio Dalam Menarik Minat Pendengar (Studi di Radio Komunitas Dwijendra), Jurnal Kajian Ilmu Komunikasi, 16(1).

Morissan. (2018). Manajemen Media Penyiaran. Edisi Revisi: Prenada Media Group. Jakarta.

Tjiptono, F. (2012). Strategi Pemasaran. Edisi 3. Andi. Yogyakarta.

Triartanto, A. Ius. Y. (2010). Broadcasting Radio. Pustaka Book Publisher. Yogyakarta.

Vinda, MS. (2017). Programming Radio Berdasarkan Karakter Pendengar Pedesaan dan Perkotaan (Studi Kasus di Radio Pandowo Tulungagung dan She Radio Jawa Timur Surabaya). Journal of Society and Media, 1(1), 84-101. 